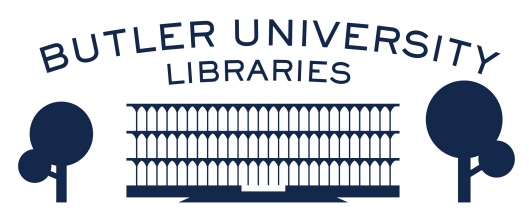

Journal of Hindu-Christian Studies

Volume 24

Article 10

November 2011

\title{
Viewpoint: Teaching Hinduism in Catholic High Schools
}

Pravrajika Saradeshaprana

Tracy Sayuki Tiemeier

Follow this and additional works at: https://digitalcommons.butler.edu/jhcs

Part of the Religion Commons

\section{Recommended Citation}

Saradeshaprana, Pravrajika and Tiemeier, Tracy Sayuki (2011) "Viewpoint: Teaching Hinduism in Catholic High Schools," Journal of Hindu-Christian Studies: Vol. 24, Article 10.

Available at: https://doi.org/10.7825/2164-6279.1487

The Journal of Hindu-Christian Studies is a publication of the Society for Hindu-Christian Studies. The digital version is made available by Digital Commons @ Butler University. For questions about the Journal or the Society, please contact cbauman@butler.edu. For more information about Digital Commons @ Butler University, please contact digitalscholarship@butler.edu. 


\section{VIEWPOINT: TEACHING HINDUISM IN CATHOLIC HIGH SCHOOLS

\author{
Pravrajika Saradeshaprana \\ Vedanta Society of Southern California \\ and \\ Tracy Sayuki Tiemeier \\ Loyola Marymount University
}

THE Los Angeles Hindu-Catholic Dialogue recently organized a workshop at Loyola Marymount University on Teaching Hinduism in Catholic High Schools (May 2010). Initiated by a Hindu member of the Dialogue who was disturbed by the World Religions textbook used in a local Catholic high school, the workshop's goal was to help teachers of World Religions at Catholic high schools teach Hindu traditions more accurately and respectfully. The daylong event featured sessions on Hindu Perspectives on Education, Resources and Strategies in Teaching Hinduism, and small group dialogues between Hindu speakers and attendees and Catholic teachers.

The organizing Dialogue group was aware of contentious issues around textbooks, which include not only the representation of Hinduism in textbooks but also the requirements by the United States Conference of Catholic Bishops for textbooks used in Catholic primary and secondary schools. While addressing these issues, emphasis was placed on constructive dialogue and resources teachers could realistically use in Catholic settings. The Los Angeles Hindu-Catholic Dialogue spent two years creating a four-page resource list for teaching Hinduism, but we were unprepared for the numerous Hindu participants and subsequent requests we received for resources in understanding Christianity. Clearly, there is much room left in the conversation!

What follows are reflections based on our presentations from the event. These reflections are focused on teaching Hinduism and world religions in Catholic high schools. Of course, the issues and methods shift in different contexts: what is appropriate at the high school level will not be appropriate at the university level, and vice versa.

Pravrajika Saradeshaprana graduated from the University of Adelaide with a Bachelor of Music degree in 1967. She came to America to join the convent of the Vedanta Society of Southern California in 1968 and received final vows of renunciation in 1979. Active in interfaith work, Saradeshaprana has written papers for domestic violence advocates on counseling Hindu clients and helped to organize conferences to educate clergy in the diagnosing and counseling of victims of domestic violence. She has taught in academic and religious environments on Hindu spiritual practices in general, but is particularly interested in women's spirituality and spiritual practices in the Hindu tradition, and Hindu puja (ritualistic worship).

Tracy Sayuki Tiemeier, Ph.D., is Assistant Professor of Theological Studies at Loyola Marymount University in Los Angeles, CA. She teaches in the areas of women and religion, Hinduism, comparative theology, Asian and Asian American theology, and faith and culture. Her research considers the intersection of race/ethnicity and gender in comparative theology and interreligious dialogue, with a particular focus on Asian and Asian American women as agents of dialogue and change. Her current project reflects on constructions of women's virtue in classical Tamil literature and devotional poetry to inform a Catholic theology of women's embodiment. Tracy also co-chairs the Los Angeles HinduCatholic Dialogue. 
We can no longer ignore the vast diversity of the world's religions, and we can no longer pretend that our own tradition is the only religion that provides enriching answers to the ultimate questions of human existence. We live, work, play, and pray next to persons of many religious traditions. We therefore owe it to our high school students to equip them with a basic knowledge of religions so they can negotiate the world around them.

Beyond basic religious literacy, there are additional reasons for interfaith education. Here in Los Angeles, we have a wonderfully rich multicultural community, but we have seen first hand what happens when understanding breaks down. We have also seen the power of interfaith understanding to hold together and build up broken communities. It was the religious infrastructure of Los Angeles that held together during the 1992 LA riots, as religious communities came together and helped the city heal. Interfaith dialogue and education helps strengthen the religious bonds in our communities, create a rich network of religious friendships, and enables us to join together to serve our community more effectively.

There are spiritual reasons for interfaith education, as well. An interfaith education looks at similarities and differences in the practices of other faiths. Through this dynamic, students are invited to see and appreciate the spiritual truths in other religious traditions. Encountering the spiritual riches of other traditions helps to deepen our own spiritual practice, in whatever shape it takes. We see our own practice in new ways, discover aspects of our own tradition that we had not previously known, and are challenged in positive ways to give an account of our faith. Interfaith education is not merely an academic exercise but contributes towards creating greater harmony in our communities and greater understanding of self, other, and ultimate reality.

Finally, there is a critical component to responsible interfaith education, even at the high school level. The dynamics of religious thought and practice are complex, multifaceted, and often ambiguous. The history of religions may testify to the power of religious tolerance, understanding, and cooperation; but it is hardly free from conflict, misunderstanding, and gross violations of humanity. While setting aside the ever-present problem of making normative claims across traditions, every religious tradition bears the weight of its past and present, which includes moments where adherents have failed to live up to the internal standards of a tradition; where leaders control religious truths for the sake of selfish goals; where practitioners battle between themselves and others over what constitutes true faith. Interfaith education must bring students to a more critical awareness of their own tradition as well as others. For without a deeper understanding of the complexities of religious traditions, students cannot move beyond naïve, immature faith or be competent to respond to the challenges of our day.

In this regard, Catholic high school interfaith education must be mindful of implications of teaching other religious traditions in its curriculum. For hundreds of years India was under foreign domination with ruling regimes that at the best misunderstood and denigrated Hinduism, and at the worst desecrated or destroyed sacred icons and persecuted those who worshiped them. The history of Christian conversion, violence, and imperialism in India therefore makes the teaching of Hinduism in Catholic contexts, even when done with the best of intentions, a sensitive topic. The issues of representation and underlying motives will inevitably be raised. Especially in religious contexts where Christian faith is taught all four years of the curriculum and without consideration of the history of Christian domination, exclusion, and injustice, the presentation of other traditions comes off as - at best - one sided and - at worst - an attempt to teach Catholic superiority and convert nonCatholic students.

A few ground rules can help navigate the dangerous waters of teaching Hinduism in Catholic high schools in a way that invites both critical understanding as well as spiritual appreciation:

1. Remember the rules of fair play. It is a fundamental principle of interfaith dialogue and comparative study not to compare the worst of someone else's religion with the best of one's own. 
48 Pravrajika Saradeshaprana and Trace Sayuki Tiemeier

2. Think globally; teach locally. Catholic American high schools are not teaching Hinduism in village India, but in contemporary America. The closest many American Hindu students have been to a cow is passing one at 70 miles an hour on the freeway. It is helpful to focus on the type of Hinduism that students are likely to experience, wherever they are. This reinforces that Hindu traditions are living traditions that shift over time and space, and adapt to their local contexts. For American Catholic students to see Hinduism as both a global and local religion is an important lesson for entering public life and for understanding the varied nature of religious traditions.

3. Present the everyday sacred. It is important at the high school level to teach daily practices and customs. Introducing students to the practices of everyday living, particularly within the home, makes any religious tradition more relatable to students, even if those practices are quite different. This knowledge will enable students, long after they have left school, to be respectful of another's religious beliefs and practices, to know how to behave when visiting a Hindu home, to be able to host Hindu friends, and to have an understanding of some of the ceremonies of the family of their friends and colleagues.

Catholic faith is not opposed to the recognition of the spiritual truths in other religions. Indeed, the tension between forming a strong Catholic identity and forming students open to the wisdom of the world can be a productive one, if we see the commitment to religious diversity as integral to the overall institutional goal of transformation and the Catholic spiritual practice of finding God in all things. Taking a more experiential approach to religious education therefore means coming clearly from one's own tradition, but learning about other and self through a dynamic, engaged encounter with other faiths and other religious persons.

This kind of approach may be a challenge for schools where a large majority of students are Catholic. However, Catholic schools everywhere are growing more and more religiously diverse, for a variety of reasons. In cases where classes have students from religious traditions other than Christianity, it behooves us to find ways for students to learn from and alongside each other about their own distinctive faith traditions. Beyond this, field trips, speakers, weekend programs, or structured retreats with young people of other traditions are invaluable practices for students. Interfaith prayer services or participation in the spiritual paths of other traditions provide deep possibilities for encounter and transformation. Yoga, meditation, and the celebration of nonChristian cultural and religious holidays are all ways in which students can see first-hand how it is that religious traditions are living, adaptable, vibrant communal realities. Through actual interfaith experiences, students learn about other persons, but they also learn more deeply about themselves and their own faith.

An experiential approach is very Hindu, though we must remember that the world of Hindu spirituality is quite different from Christian spirituality. To teach Hindu spirituality in Catholic schools, we must be prepared to challenge students to encounter themselves in a very different way. Hindu faith is not based on the divine revelation of one male founder. The way Hindus view religious texts and mystical experience is very different. There is not a divinely revealed, institutionally sanctioned legal system that places a universal standard of conduct on all its adherents. Hindus have no particularly recognized spokesperson with an official view on almost any subject. In some schools of Hinduism, sacred self is conceived in terms of a relationship with God (one's real identity is that of a child of the Divine Mother, or the servant of God, or the friend of God), while other schools conceive sacred self as nondifferential union with Brahman, the allpervading Divine Reality. Nevertheless, experiential realization is central for Hindu traditions, however differently that may be envisioned and practiced. Such an experiential emphasis is a powerful place to begin teaching Hinduism in Catholic high schools; for it offers a starting point for exploring Hinduism that can both highlight the similarities and differences with Christianity, as well as ground that exploration in a spiritual journey.

After grounding the study of Hinduism in 
spiritual experience, knowledge, and encounter, high school students are more able to move to the critical study of Hinduism. Such a move is based on theories of religious education, which approach religious education developmentally. As a young person grows in understanding, she is more equipped to ask difficult questions about her tradition and come to a critical faith. Similarly, from the standpoint of experiential appreciation of a living and vibrant Hinduism, a student is better able to look at some of the difficult questions that vex all religious traditions.

Toward that end, we'd like to conclude with two particularly contentious issues for teaching Hinduism: gender and caste. Religion is inevitably entangled in the socio-political. Cultural views of gender and class influence religious views of gender and class, and religious views in turn sanction cultural perspectives. Yet, although religion is embedded in a cultural context, it can be (at least partially) distinguished. Thus, essential to the critical study of religion is teaching students the ability to understand religion as a part of culture while yet helping them (as quixotic a task as it may be) to discern between what elements of a religious tradition reflect cultural attitudes that can and do shift over time and what elements are properly religious.

Both gender and caste are controversial topics, and they can be used to essentialize Hinduism and reinforce Christian hegemony. Particularly in a tightly governed Catholic curriculum that forbids a full exploration of gender in Christianity (say to consider Catholic support for same-sex marriage or women's ordination), Catholicism is given a free pass while Hinduism is not. In fact, gender and class/caste/racial discrimination have been and are given religious sanction in many religious traditions - including Christianity. This is not to say that therefore Hinduism should be given a pass. What it means is that we can and should discuss gender and caste, but it must be done with intellectual honestly and in the context of critical approaches to all the traditions under consideration.

While it cannot (nor should not) be denied that Hindu cultural and religious attitudes about women have interacted in sometimes disastrous ways, the reality of gender in Hinduism is far more complex than it may at first appear. There are innumerable Hindu women's rituals, spiritualities, saints, and theo(a)logies that are essential for understanding Hinduism. Moreover, polyvalent discourses and practices of gender complementarity, gender reversal, and gender multiplicity abound. Ultimately, gender is so varied and fluid in Hindu traditions, any assertion about gender in Hinduism must be contextualized and counterbalanced.

There must also be a balanced discussion of caste in the Catholic high school classroom. While caste discrimination and violence continues, caste must not be presented as a monolithic, unchanging reality. Hindu attitudes toward caste across time have differed and even contradicted each other. Religious arguments for and attempts at caste reform, caste subversion, and even caste eradication occurred long before Gandhi. Moreover, caste crosses Indian religious traditions (including Indian Catholic and Indian American Catholic traditions), making the religious and social dimensions of caste muddy and complicated.

It is unrealistic to think that Catholic schools have the freedom to explore Catholic sexism, heterosexism, and racism as fully as with Hinduism. But this is precisely the problem, as it clearly violates our first rule in interfaith education of fair play. Is it intellectually honest or fair to take a critical approach to Hinduism but not with Catholicism? We urge Catholic high school teachers to treat difficult topics in other religious traditions as one would treat difficult topics in Catholicism. Yes, take a critical approach, but do so with sensitivity.

In the end, to ignore the difficult issues religions face is just as problematic as presenting unbalanced perspectives on them. To face them head on provides a powerful opportunity to educate for justice. In America, we live in a supposedly post-feminist, post-racial society. Those of us who see continued discrimination and violence based on gender, sexual orientation, and race know that America has much work to do before we can claim such a reality. In the context of an interfaith education at a Catholic high school, students can learn 
50 Pravrajika Saradeshaprana and Trace Sayuki Tiemeier

where Christians and Hindus have contributed to the problems of past and present but also where they have been powerful leaders for a just society. The collective resources in both traditions can be studied and retrieved as students become thoughtful, faithful, and ethical adults. 